\title{
ACTIVE ROTOR VIBRATION CONTROL
}

\begin{abstract}
Summary
The article deals with the analysis of active vibration control of a rotor which is supported by journal bearings. The oil film between the journal and bushing induces the rotor instability, which causes rotor vibrations if rotational speed is greater than a threshold of system stability. This phenomenon is very important for high-speed rotational machines for which restricts the operational range of the rotational speed. Therefore increasing the rotor stability threshold is very important for preventing rotor vibrations. The rotor instability results in lateral vibrations which do not conform to the forces of the unbalanced masses or other external forces. The frequency of the lateral vibration is slightly less than half of the rotational frequency. The main result of the article is the analytical determination of the influence of the setting of the PD type controller on the threshold of stability.
\end{abstract}

Keywords: active vibration control, rotor vibration, journal bearings

\begin{abstract}
AKTYWNE STEROWANIE DRGANIAMI WIRNIKA
Artykut omawia analize aktywnego sterowania drganiami wirnika podpartego tożyskami ślizgowymi. Film olejowy w szczelinie pomiędzy czopem i panwia tożyska wywohuje niestabilność wirnika, co dla prędkości obrotowej większej od progu stabilności systemu powoduje jego drgania. Zjawisko to jest bardzo ważne dla maszyn o wysokich prędkościach obrotowych, ponieważ ogranicza zakres prędkości roboczych. Dlatego podwyższenie progu stabilności wirnika jest bardzo znaczace dla zapobiegania drgań wirnika. Niestabilność wirnika przejawia się drganiami poprzecznymi, które nie sa w zgodzie z siłami niewyważenia oraz pozostalymi siłami zewnętrznymi. Częstotliwość tych drgań poprzecznych jest nieco mniejsza niz polowa częstotliwości obrotowej wirnika. Podstawowym wkladem artykułu jest analityczne pokazanie wplywu regulatora PD na próg stabilności wirnika.
\end{abstract}

Stowa kluczowe: aktywne sterowanie drganiami, drgania wirnika, tożyska ślizgowe

\section{INTRODUCTION}

A rotor dynamics and a rotor vibration are extensively studied in present publications (Adams 2010, Dimarogonas et al. 2013, Gash et al. 2006, Muszyńska 2005, Kiciński 2002, Kowal 1996), especially in technical papers (Cheng et al. 2006, Ding et al. 2002, Gosiewski, Górmiński 2006, Li et al. 2003, Li et al. 2007, Muszyńska, Bently 1989 and 1996, Tuma et al. 2007, Tuma et al. 2008). But there are significantly fewer publications dealing with an active vibration control of the rigid rotor housed in journal bearings (Tuma et al. 2013, Vitecek et al. 2008, Vitecek et al. 2010). With increasing rotational speed of the rigid rotor housed in journal bearings the hydrodynamic lubrication appears. It creates the oil wedge and for the overrun of the rotational speed which corresponds the Bently-Muszynska stability threshold it can cause lateral vibration of the journal in the bearing, and thus the rotor instability (Muszyńska 2005, Muszyńska, Bently 1989 and 1996, Tuma et al. 2007, Tuma et al. 2008). The rotor instability strongly limits the maximum usable rotational speed. The passive control is based on improvement of the bushing geometry which influences the flow of the lubricant while the active control uses an electronic feedback which actuates the bushing position with the use of piezoactuators according to the rotor position which is sensed by proximity probes. The controlled system has two inputs and two outputs because it is used a pair of the actuators and a pair of the position sensors. The article is devoted to the analysis of the active vibration control of the rigid rotor which is supported by journal hydrodynamic bearings.

\section{STABILITY THRESHOLD}

The simplified stationary linear mathematical model of a rigid rotor housed in a journal bearing (fig. 1), i.e. the system 'rotor - bearing', assuming that only its mass and behaviour of the oil film are considered in the equation of motion, can have the vector form (Muszyńska 2005, Muszyńska, Bently 1996, Tuma et al. 2007, Tuma et al. 2008):

$$
\begin{aligned}
& M \ddot{\mathbf{r}}+D \dot{\mathbf{r}}+(K-j D \lambda \Omega) \mathbf{r}=\mathbf{f} \\
& \mathbf{r}=x+j y
\end{aligned}
$$

where $M$ is the total rotor mass $[\mathrm{kg}], D$ - the generalized damping coefficient $[\mathrm{N} \mathrm{s} / \mathrm{m}], K-$ the generalized stiffness coefficient $[\mathrm{N} / \mathrm{m}], \lambda-$ the value of the oil circumferential average velocity ratio [-], $\Omega-$ the rotor angular velocity $[\mathrm{rad} / \mathrm{s}]$,

\footnotetext{
* Faculty of Mechanical Engineering, VSB - Technical University of Ostrava, Czech Republic; miluse.viteckova@vsb.cz, antonin. vitecek@vsb.cz,jiri.tuma@vsb.cz
} 
$x$ - the horizontal displacement of the rotor centre [m], $y$ - the vertical displacement of the rotor centre [m], $\boldsymbol{f}$ - the vector of the external forces, $j$ - the imaginary unit.

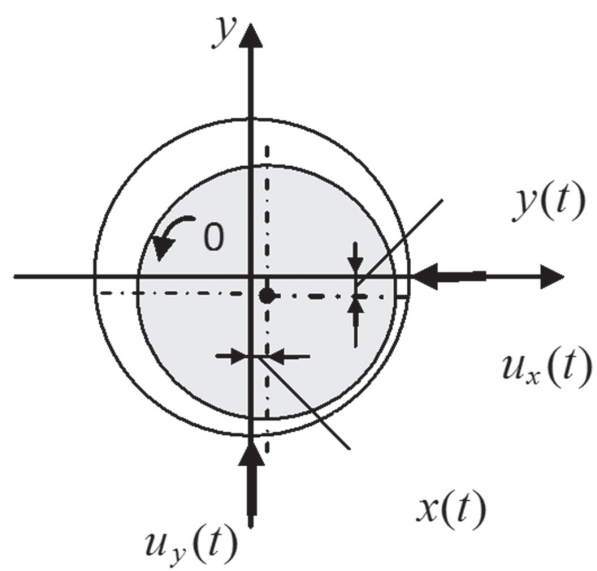

Fig. 1. Rotor journal in sliding bearing

The stability of the system 'rotor - bearing' can be verified with the use of the characteristic polynomial of equation (1a):

$$
N(s)=M s^{2}+D s+(K-j D \lambda \Omega)
$$

The characteristic polynomial (2) contains the complex coefficient; therefore the Mikhaylov stability criterion will be used (Park, Hahn 1993).

The Mikhaylov hodograph $N(j \omega)$ is given by relation:

$$
N(j \omega)=\left.N(s)\right|_{s=j \omega}=K-M \omega^{2}+j D(\omega-\lambda \Omega)
$$

where $\omega$ is the angular frequency $[\mathrm{rad} / \mathrm{s}], s-$ the complex variable.
Because the Mikhaylov hodograph $N(j \omega)$ is not an even function, therefore it has to be plotted for the angular frequencies $-\infty<\omega<\infty$. In accordance to the Mikhaylov criterion the system 'rotor - bearing' will be stable if the increment of the argument will be equal (fig. 2) (Park, Hahn 1993):

$$
\Delta \arg N(j \omega)=2 \pi
$$

From figure 2 it follows that the stability condition (4) will be fulfilled if the point of intersection of the Mikhaylov hodograph $N(j \omega)$ with the imaginary axes for the angular frequency:

$$
\omega=\sqrt{\frac{K}{M}}
$$

will be over the coordinate origin, i.e.:

$$
\sqrt{\frac{K}{M}}-\lambda \Omega>0 \Rightarrow \Omega<\frac{1}{\lambda} \sqrt{\frac{K}{M}}
$$

The critical value of the angular rotor velocity:

$$
\Omega_{c r}=\frac{1}{\lambda} \sqrt{\frac{K}{M}}
$$

expresses the Bently-Muszyńska (in)stability threshold (the oscillating stability boundary) (Muszyńska 2005, Muszyńska, Bently 1989 and 1996, Tuma et al. 2007, Tuma et al. 2008, Tuma et al. 2013, Vitecek et al. 2008, Vitecek et al. 2010).

\section{ACTIVE INCREASING OF STABILITY THRESHOLD - LINEAR MODEL}

Increasing the critical angular rotor velocity can be achieved by modification of the journal bushing shape, respectively by their lubrication. An essential decreasing of the rotor vibra-

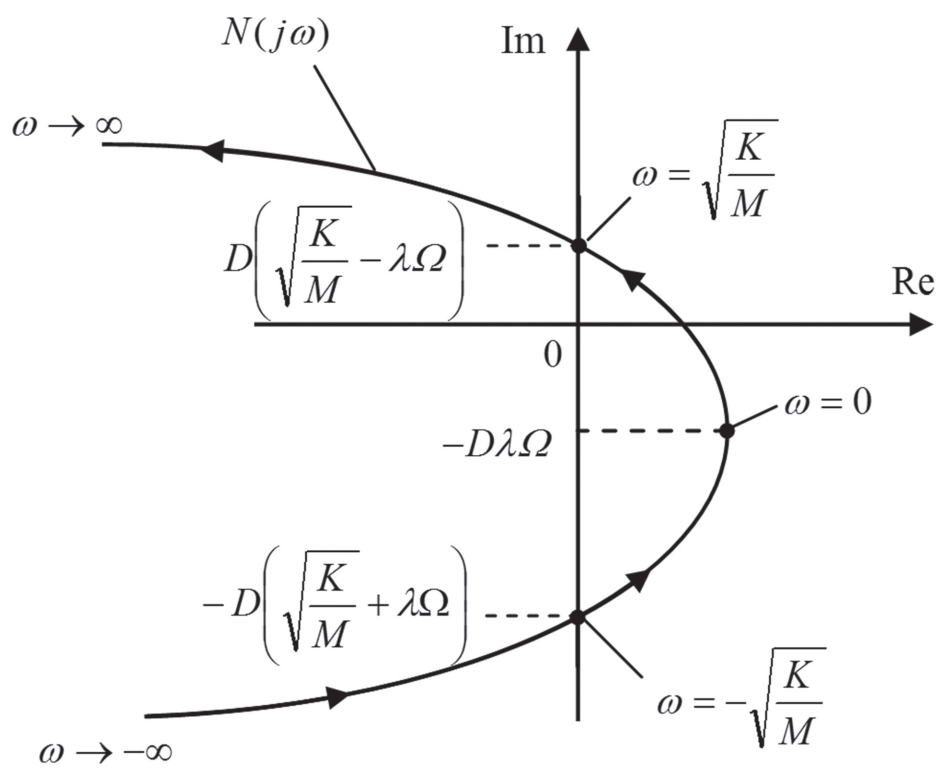

Fig. 2. Mikhaylov hodograph of the system 'rotor - bearing' 


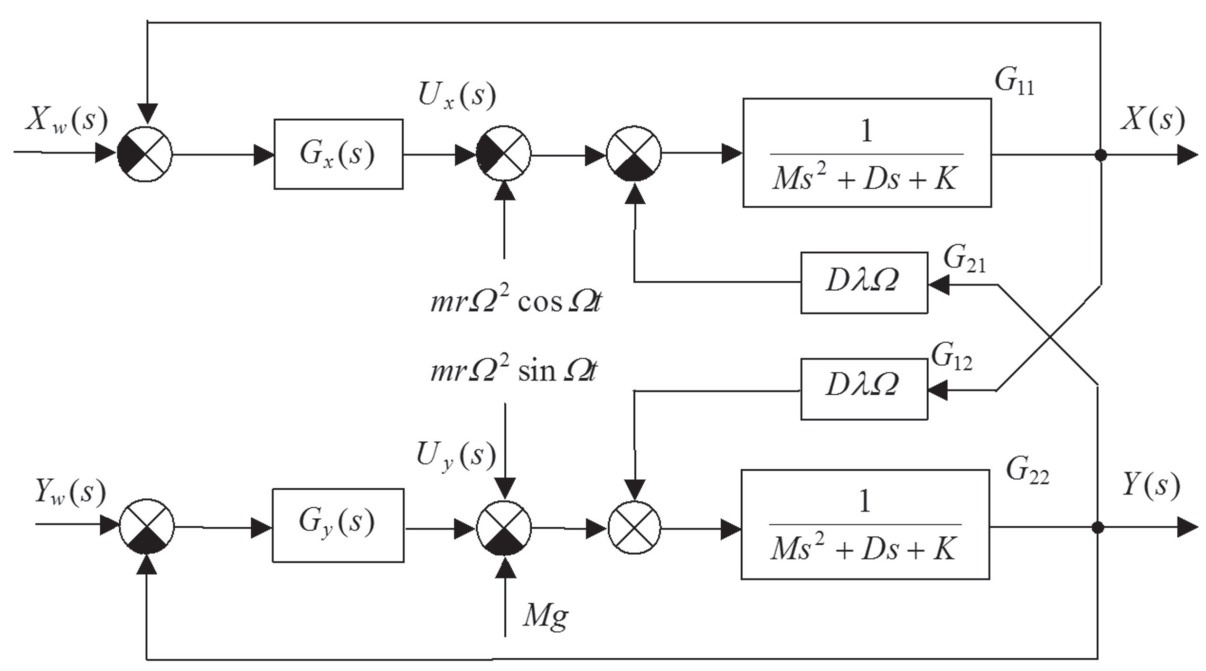

Fig. 3. Linear TITO control system for stabilization of system 'rotor - bearing'

tion, i.e. increasing the stability threshold, can be also achieved by active actuating the position of the journal bushing.

One from possibilities is using the decentralized TITO (two-inputs two-outputs) control system in figure 3 with the control objective (Vitecek et al. 2008, Vitecek et al. 2010):

$$
\left\{\begin{array}{l}
X(s) \rightarrow X_{w}(s)=0 \\
Y(s) \rightarrow Y_{w}(s)=0
\end{array}\right.
$$

The mathematical model of the system 'rotor - bearing' in the vector form (1) is not suitable for control synthesis. Therefore the vector model (1a) on the basis of (1b) can be rewrite in the component form:

$$
\left\{\begin{array}{l}
M \ddot{x}(t)+D \dot{x}(t)+K x(t)+D \lambda \Omega y(t)=f_{x}(t) \\
M \ddot{y}(t)+D \dot{y}(t)+K y(t)-D \lambda \Omega x(t)=f_{y}(t)
\end{array}\right.
$$

where the external forces are given by relations:

$$
\left\{\begin{array}{l}
f_{x}(t)=-u_{x}(t)+m r \Omega^{2} \cos \Omega t \\
f_{y}(t)=u_{y}(t)-M g+m r \Omega^{2} \sin \Omega t
\end{array}\right.
$$

where $u_{x}$ is the actuator horizontal force $[\mathrm{N}], u_{y}$ - the actuator vertical force $[\mathrm{N}], g-$ the acceleration of gravity $\left[\mathrm{m} / \mathrm{s}^{2}\right]$, $m$ - the unbalanced mass $[\mathrm{kg}], r-$ the radius for the unbalanced mass [m].

In accordance to figure 3 it is possible to write (for the reason of simplicity the independent complex variable $s$ is not often explicitly written):

$$
\left\{\begin{array}{l}
X=\frac{G_{11}}{1+G_{x} G_{11}}\left(G_{x} X_{w}+V_{x}-G_{21} Y\right) \\
Y=\frac{G_{22}}{1+G_{y} G_{22}}\left(G_{y} Y_{w}+V_{y}+G_{12} X\right)
\end{array}\right.
$$

where $G_{x}$ and $G_{y}$ are the controller transfer functions, $V_{x}$ and $V_{y}$ - the transforms of the disturbances (unbalanced mass and gravitational force):

$$
\left\{\begin{array}{l}
v_{x}(t)=m r \Omega^{2} \cos \Omega t \\
v_{y}(t)=m r \Omega^{2} \sin \Omega t-M g
\end{array}\right.
$$

The mathematical model of the system 'rotor - bearing' without the effect of the unbalanced mass and gravitational force is in figure 4. The V-structure of the model of the system 'rotor - bearing' is shown in figure $4 \mathrm{a}$, where:

$$
\left\{\begin{array}{l}
G_{11}(s)=G_{22}(s)=\frac{1}{M s^{2}+D s+K} \\
G_{12}(s)=G_{21}(s)=D \lambda \Omega
\end{array}\right.
$$

The P-structure of the mathematical model in figure $4 \mathrm{~b}$ is suitable for verification of the stability of the system 'rotor - bearing' and the synthesis of the TITO control system, where:

$$
\left\{\begin{array}{l}
G_{P 11}(s)=G_{P 22}(s)=\frac{M s^{2}+D s+K}{\left(M s^{2}+D s+K\right)^{2}+D^{2} \lambda^{2} \Omega^{2}} \\
G_{P 12}(s)=G_{P 21}(s)=\frac{D \lambda \Omega}{\left(M s^{2}+D s+K\right)^{2}+D^{2} \lambda^{2} \Omega^{2}}
\end{array}\right.
$$

It is obvious that the characteristic polynomial of the system 'rotor - bearing' has the form:

$$
\begin{aligned}
N_{P}(s) & =\left(M s^{2}+D s+K\right)^{2}+D^{2} \lambda^{2} \Omega^{2}= \\
& =M^{2} s^{4}+2 D M s^{3}+\left(2 K M+D^{2}\right) s^{2} \\
& +2 D K s+D^{2} \lambda^{2} \Omega^{2}+K^{2}
\end{aligned}
$$

from which it can be obtained the stability condition in the form:

$$
\Omega<\frac{1}{\lambda} \sqrt{\frac{K}{M}}
$$

considering the Hurwitz criterion. It is obvious that it must be identical like (5). 
a)

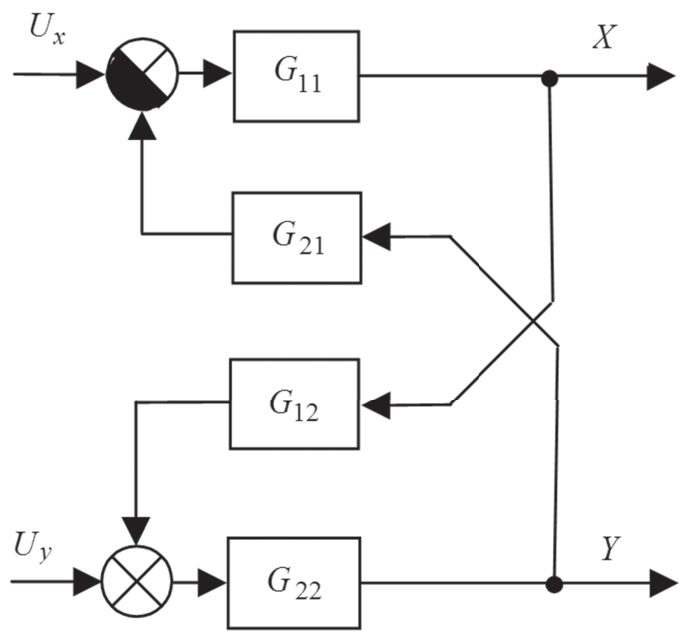

b)

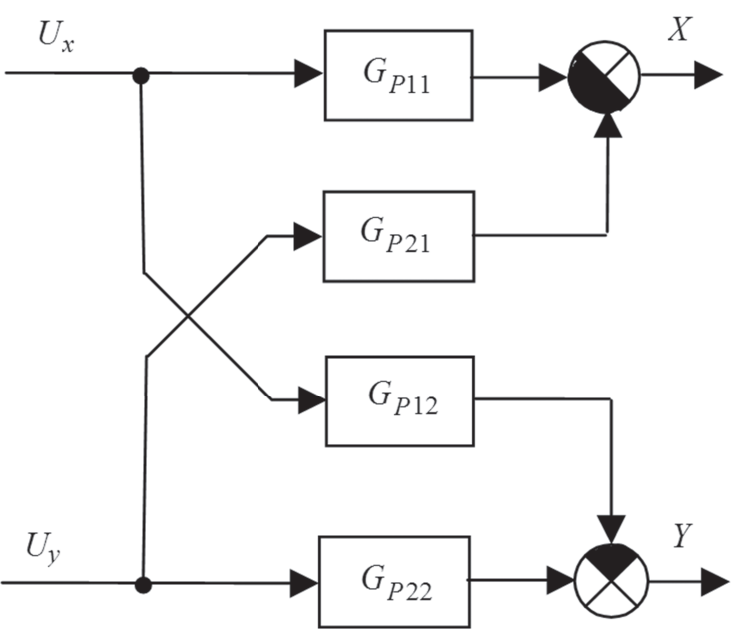

Fig. 4. Block diagram of system 'rotor - bearing': a) V-structure, b) P-structure

By the rewriting of the (10) it is possible to obtain:

$$
\left\{\begin{array}{rl}
X=\frac{G_{11}}{\left(1+G_{x} G_{11}\right)\left(1+G_{y} G_{22}\right)+G_{11} G_{12} G_{21} G_{22}} \\
\cdot\left[\left(1+G_{y} G_{22}\right) G_{x} X_{w}-G_{21} G_{y} G_{22} Y_{w}+\right. \\
\left.+\left(1+G_{y} G_{22}\right) V_{x}-G_{21} G_{22} V_{y}\right]
\end{array} .\right.
$$

The characteristic polynomial $N(s)$ of the TITO control system in figure 3 can be obtained after modification of the relations (16) from any their denominators.

Assuming that the both controllers are of the same PD type (the use of controllers with the integrating component is for analytical computation more difficult), i.e. the transfer functions of the controllers are as follows:

$$
G_{x}(s)=G_{y}(s)=k_{P}\left(1+T_{D} s\right)
$$

then the characteristic polynomial has the form:

$$
\begin{aligned}
N(s) & =M^{2} s^{4}+2 M\left(D+k_{P} T_{D}\right) s^{3}+ \\
& +\left[\left(D+k_{P} T_{D}\right)^{2}+2 M\left(K+k_{P}\right)\right] s^{2}+ \\
& +2\left(D+k_{P} T_{D}\right)\left(K+k_{P}\right) s+\left(K+k_{P}\right)^{2}+ \\
& +(D \lambda \Omega)^{2}
\end{aligned}
$$

where $k_{P}$ is the controller gain, $T_{D}$ - the controller derivative time constant.

Using the Hurwitz criterion the stability condition can be calculated in the form:

$$
\Omega<\frac{1}{\lambda} \sqrt{\frac{K+k_{P}}{M}+\frac{\left(K+k_{P}\right)\left(2 D+k_{P} T_{D}\right) k_{P} T_{D}}{M D^{2}}}
$$

From the condition (19) it is obvious that by the use of the decentralized TITO control system with the PD controllers increases the stability threshold of the rotational speed which is originally defined by the formula (6). For $k_{P}=0$ the condition (5) or (15) is obtained. Because the controllers (17) don't contain the integrating component the displacement of the rotor centre relative to the centre of the journal bearing resulting from presence of the gravity force wouldn't be removed, but for sufficiently high values of the controller gains $k_{P}$ it will be essentially suppressed. The harmonic influences caused by the unbalanced mass cannot be fully removed even by the use of the controllers with the integrating component.

All theoretical conclusion for the linear mathematical model of the system 'rotor - bearing' and the TITO control system with decentralized controllers P, PD, PI and PID were confirmed by the digital simulation (Vitecek et al. 2008, Vitecek et al. 2010).

\section{ACTIVE INCREASING \\ OF STABILITY THRESHOLD - NONLINEAR MODEL}

Further it is supposed that the nonlinear mathematical model of the system 'rotor - bearing' has the same form like (1) or (8), but the generalized coefficients $D, K$ and $\lambda$ are nonlinear functions of the relative radial eccentricity:

$$
e=\frac{1}{c} \sqrt{x^{2}+y^{2}}
$$

where $c$ is the radial clearance $[\mathrm{m}]$.

The following formulas are very often used (Cheng et al. 2006, Ding et al. 2002, Li et al. 2003, Li et al. 2007) for approximation of stiffness $K$, damping $D$ and circumferential average velocity ratio $\lambda$ as functions of the relative radial eccentricity: 

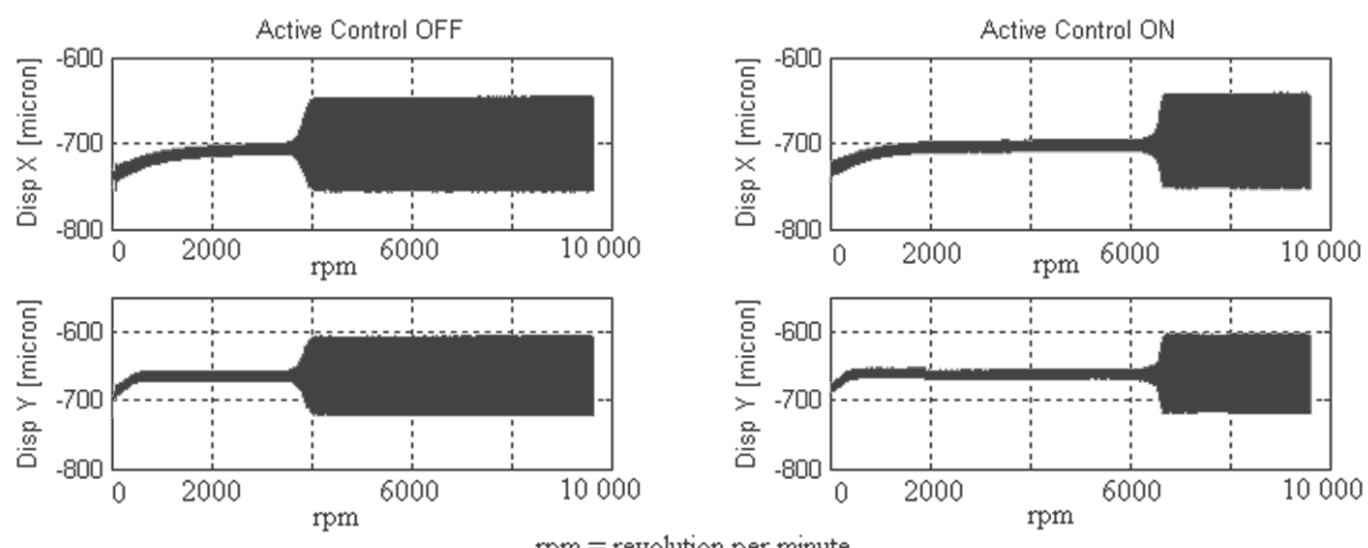

Fig. 5. Onset of rotor instability (vibration) on the test rig: a) without control, b) with control

$$
\begin{aligned}
& K=K_{0}\left(1-e^{2}\right)^{-n}, D=D_{0}\left(1-e^{2}\right)^{-n}, n=0.5 \div 3 \\
& \lambda=\lambda_{0} /(1-e)^{b}, \quad 0<b<1
\end{aligned}
$$

where $K_{0}$ is the initial value of the generalized stiffness coefficient $[\mathrm{N} / \mathrm{m}], D_{0}-$ the initial value of generalized damping coefficient $[\mathrm{N} \mathrm{s} / \mathrm{m}], \lambda_{0}-$ the initial value of the oil circumferential average velocity ratio $[-]$.

The nonlinear dependence of the parameters $D, K$ and $\lambda$ (21) and (22) on the relative radial eccentricity (20) has the positive influence on the rotor stability.

Also in this case the verification of these theoretical conclusions was provided by digital simulation (Vitecek et al. 2008) and on a laboratory test rig (Tuma et al. 2013, Vitecek et al. 2010). The results obtained for decentralized proportional controllers on the real test rig (fig. 5) show that the rotor vibration can be considerably decreased by the active vibration control.

\section{CONCLUSIONS}

The paper describes a new approach to increase the stability threshold of the rigid rotor housed in journal bearings by means of force acting by way of a special bushing on the journal in the bearing. The electronic feedback and the piezoactuators in the control system increase the instability threshold and simultaneously decrease the rotor vibration.

It was proved analytically and by the digital simulation and also experimentally on the real laboratory rig that the active rotor vibration control can considerably increase the operational rotational speed and therefore there are good assumptions for its practical applications.

The work was supported by research project GACR No. $101 / 12 / 2520$.

\section{References}

Adams M.J 2010, Rotating Machinery Vibration. 2nd ed., CCR Press Taylor \& Francis Group, Boca Boston.

Cheng M., Meng G., Jing J. 2006, Non-linear Dynamics of a Rotor-bearing-seal System. Arch. Appl. Mech., vol. 76, pp. 215-227.

Dimarogonas A.D., Paipetis S.A., Chondros T.G. 2013, Analytical Methods in Rotor Dynamics. 2nd ed., Springer, Dordrecht.

Ding Q., Cooper J. E., Leung A.Y.T. 2002, Hopf Bifurcation Analysis of a Rotor/Seal System. Journal of Sound and Vibration, vol. 252 (5), pp. 817-833.

Gash R., Nordmann R., Pfützner H. 2006, Rotordynamik. 2., vollständing neu bearbeitete und erweiterte Auflage, Springer, Berlin.

Gosiewski, Z., Górmiński M. 2006, Identification of Physical Parameters of Rigid Rotor in Magnetic Bearings. Mechanics, vol. 25, no. 2, pp.64-71.

Kiciński J. 2002, Dynamika wirników i tożysk ślizgowych. Wydawnictwo IMP PAN, Gdańsk.

Kowal J. 1996, Sterowanie drganiami. Gutenberg, Kraków.

Li S., Xu Q., Wan F., Zhang X. 2003, Stability and Bifurcation of Unbalance Rotor/Labyrinth Seal System. Applied Mathematics and Mechanics, English Edition, vol. 24, no. 11, Nov. 2003, pp. 1290-1300.

Li S., Xu Q., Zhang X. 2007, Nonlinear Dynamic Behaviours of a Rotor-labyrinth Seal System. Nonlinear Dyn., vol. 47, pp. 321-329.

Muszyńska A., Bently D. E. 1989, Fluid-generated Instabilities of Rotors. Orbit, April, pp. 6-14.

Muszyńska A., Bently, D.E. 1996, Fluid-induced Instabilities of Rotors: Whirl and Whip - Summary Results. Orbit, March, pp. 7-15.

Muszyńska A. 2005, Rotordynamics. Taylor \& Francis, New York.

Parks P.C., Hahn V. 1993, Stability Theory. Prentice Hall, New York.

Tuma J., Bilos J. 2007, Fluid Induced Instability of Rotor Systems with Journal Bearings. Engineering Mechanics, vol. 14, no. 1/2, pp. 69-80.

Tuma J., Bilosova A., Simek J., Svoboda R. 2008, A Simulation Study of the Rotor Vibration in a Journal Bearing. [in:] Proccedings of the Colloquium DYNAMICS OF MACHINES 2008, 8 p.

Tuma J., Simek J., Skuta J., Los J. 2013, Active vibration control of journal bearing with the use of piezoactuators. Mechanical Systems and Signal Processing, vol. 36, pp.618-629.

Vitecek A., Tuma J., Viteckova M., Koci P. 2008, Active Rotor Threshold Stability Control (in Czech). Acta Mechanica Slovaca, vol. 12, no. 1-A, pp. 13-18.

Vitecek A., Tuma J., Viteckova M. 2010, Active control of rotor stability. [in:] Proceedings of the $11^{\text {th }}$ International Carpathian Control Conference ICCC'2010, Eger, Hungary, May 26-28, pp. 517-520. 